\title{
Specify HPV Genotype
}

National Cancer Institute

\section{Source}

National Cancer Institute. Specify HPV Genotype. NCI Thesaurus. Code C157110.

A directive to specify the genotype determined by HPV Genotyping. 